\title{
Intralingual subtitles, interlingual subtitles, and video comprehension: insights from an exploratory study
}

\section{Legendas intralinguais, legendas interlinguais e compreensão de vídeo: percepções a partir de um estudo exploratório}

Rafael Matielo ${ }^{1}$, Roberta Pires de Oliveira ${ }^{2}$, Luciane Baretta $^{3}$

Doutor em Letras/Inglês: Estudos Linguísticos e Literários pela Universidade Federal de Santa
Catarina (UFSC) e Professor Adjunto na Universidade Federal do Ceará (UFC), no Departamento de Estudos da Língua Inglesa, suas Literaturas e Tradução (DELILT).

E-mail: rafaelmatielo@yahoo.com.br

Doutora em Linguistica pela Katholieke Universiteit de Santa Catarina (UFSC) Atua no Programa Pós-Graduaçấo em Linguística da Universidade Federal do Paraná (UFPR) e no Programa de Pós-Graduação em Inglês: Estudos Linguísticos e Literários da UFSC.

E-mail: rapiolive@gmail.com

Doutora em Letras/nglês: Estudos Linguísticos Catarina (UFSC) e dosidade Federal de Santa Centro-Oeste (UNICENTRO), em Guarapuava-PR. Atua no Programa de Pós-Graduação em Letras da UNICENTRO.

E-mail: barettaluciane@gmail.com
ABSTRACT: This paper explores the effects of intralingual and interlingual subtitles on Brazilian English as a Foreign Language (EFL) learners processing and video comprehension of a North-American sitcom. More specifically, it looks at the effects of intralingual and interlingual subtitles on learners' general and specific video comprehension. Thirty-six intermediate-level EFL learners, enrolled at the Extracurricular Language Courses at Universidade Federal de Santa Catarina (UFSC), were equally divided into two experimental groups (intralingual subtitles and interlingual subtitles) and one control group (no subtitles). Participants' performance was measured based on a general and specific video comprehension test. Data were analyzed both quantitatively and qualitatively. Regarding the effects of subtitles on video comprehension, statistical tests and analyses performed revealed that intralingual subtitles were found to be more beneficial in terms of learners' general and specific video comprehension than interlingual subtitles, which in turn were found to be more effective than no subtitles. Still, participants' performance in the experimental conditions did not differ statistically. These results are discussed in light of the possible different processing mechanisms and potentials that both intralingual and interlingual subtitles may offer for L2 learning/instructional purposes.

Keywords: Intralingual subtitles; Interlingual subtitles; Video comprehension; Sitcom.

RESUMO: Este estudo explora os efeitos de legendas intralinguais e interlinguais no processamento e compreensão de um sitcom norte-americano por brasileiros aprendizes de Inglês como Língua Estrangeira (ILE). Mais especificamente, este trabalho investiga os efeitos de legendas intralinguais e interlinguais na compreensão geral e específica do vídeo por parte dos aprendizes. Trinta e seis aprendizes de ILE, matriculados nos Cursos Extracurriculares de Língua da Universidade Federal de Santa Catarina (UFSC), foram igualmente divididos em dois grupos experimentais (legendas intralingual e legendas interlinguais) e um grupo controle (sem legendas). 0 desempenho dos participantes foi medido com base em um teste de compreensão geral e específica do vídeo. Os dados foram analisados quantitativa e qualitativamente. Em relação aos efeitos das legendas na compreensão do video, os testes estatísticos e as análises revelaram que as legendas intralinguais foram mais benéficas para a compreensão geral e específica dos aprendizes do que as legendas interlinguais. Estas, por sua vez, foram mais benéficas do que a condição controle. Contudo, o desempenho dos participantes nas condições experimentais não mostrou diferenças estatísticas. Os resultados são discutidos à luz de diferentes possíveis mecanismos de processamento e potenciais que os tipos de legendas podem oferecer para a aprendizagem/instrução em L2.

Palavras-chave: Legendas intralinguais; Legendas interlinguais; Compreensão de vídeo; Sitcom. 


\section{Introductory Remarks}

The disciplinary field of Second Language Acquisition (henceforth

SLA) seems to have begun receiving an increasing worldwide scholar attention in terms of the investigation of the use of subtitled videos in and outside language classrooms. Ever since Karen Price's groundbreaking work in 1983, a considerable body of knowledge of the effects of and the effects with subtitles for language instruction/learning purposes has been gathered. Throughout the last thirty years or so, researchers have steadily taken meaningful steps towards a more solid understanding of how leaners may benefit from subtitling in terms of their language development. Nonetheless, despite what may seem to be a long period of academic inquiry, much is still unknown (VANDERPLANK, 2015).

According to Koolstra and Beentjes (1999), such increasing interest in the potentials of subtitled video materials for language learning might stem from the fact that they "seem to provide a rich context for foreign language acquisition" (p. 51). Furthermore, some scholars have advocated for the use of the First Language (L1) as a valuable resource in the classroom (ATKINSON, 1987; AUERBACH, 1993; ROMANELLI, 2009), which might help explain the driving force behind the use of subtitled materials for language teaching and learning.

In order to make videos accessible to populations that do not fully know the language spoken in the dialogues of the videos or to facilitate students' overall comprehension, subtitles tend to be used. Regarding this translational aid, an important distinction merits closer attention: while interlingual subtitles ${ }^{1}$

\footnotetext{
Interlingual subtitles are also commonly referred to as standard subtitles or simply as subtitles, that is, the type of translational aid involving one linguistic pair (when soundtrack and subtitles present two different type of translational aid inolving one lingustic pair (when soundtrack and subties prestit two diserent prent the sam loy observed (DANAN, 2004).
}

specifically refer to target-language texts, varying depending on the country, typically displayed at the bottom of the screen, intralingual subtitles refer to same-language subtitles (also known as captions), which originally had the function to serve the hearing-impaired (NEUMAN \& KOSKINEN, 1992).

The instructional use of subtitled video materials also seems to have been pushed forward by some other specific reasons. According to Neuman and Koskinen (1992), it is noteworthy to mention that: (i) videos' combination of sounds and pictures might enhance the relationship between words and meanings; (ii) videos have entertainment qualities that constitute a potential advantage over static texts; and (iii) viewing could be perceived as a cognitively active experience - when suitable material is used (ANDERSON \& COLLINS, 1988; NEUMAN, 1989). Moreover, from a learning styles standpoint, subtitled videos might cater for different types of learners, such as visual and auditory ones at the very same time.

Studies on the instructional and non-instructional use of interlingual and intralingual subtitled videos have addressed a number of topics that include, but are not limited to: the improvement of Foreign/Second Language $(L 2)^{2}$ reading (MARKHAM \& PETER, 2003; CHEN, 2012; KRUGER \& STEYN, 2014; SU \& LIANG, 2015), L2 listening comprehension with/without L2 vocabulary learning (GARZA, 1991; HUANG \& ESKEY, 1999; MARKHAM, PETER, \& MCCARTHY, 2001; STEWART \& PERTUSA, 2004; TAYLOR, 2005; WINKE, GASS, \& SYDORENKO, 2010; WANG, 2012), L2 vocabulary learning per se (BIANCHI \& CIABATTONI, 2008; D’YDEWALLE \& VAN DE POEL, 1999; MATIELO, COLLET, \& D’ELY, 2013; PETERS, HEYNEN, \& PUIMĖGE, 2016), the effects on implicit and explicit memory and cognitive processing (BIRD \&

2 The importance, implications, and underlying assumptions that the terms Foreign Language and Second Language pose are not to be discorded Also, we are aware of the differences between these two terms, as posed by Krasen (1982/2009) but we side with Ellis (2008), dho argues that for now, it is better not to treat these two situtions as different since it still rot in each of them are. Hence, L2 will be used as an umbrella term in the present study. 
WILLIAMS, 2002), and the acquisition of L2 grammar (BIANCHI \& CIABATTONI, 2008; VAN LOMMEL, LAENEN, \& D’YDEWALLE, 2006; SAEEDI \& BIRI, 2016).

Though the significant number of studies previously mentioned signals a prolific niche of research in SLA, one might contend that the investigation of the use of subtitled video materials upon any domain of L2 learning does not seem to take a central position in the research agenda within the field. Furthermore, provided the lack of subtitling studies involving the Brazilian population, this paper intends to contribute to the study of the effects of intralingual and interlingual subtitles on language learning, more specifically on how these translational aids affect general and specific video comprehension in terms of the story narrated on screen.

This article, a spinoff of a PhD dissertation, has been organized into five sections including this introductory one. Section 2 presents a brief review of the literature, epitomizing the complexities and the number of unresolved issues concerning the benefits and drawbacks of intralingual and interlingual subtitles for L2 learning purposes. Section 3 centers on the main methodological aspects informing this study. Section 4 focuses on the descriptive statistics, the results, and the discussion of the main findings. Finally, section 5 offers a summary of the key findings as well as some limitations and implications that have emerged.

\section{Intralingual subtitles vs. interlingual subtitles: what we do and do not know yet}

To date, one of the undeniable aspects that we do know regards the fact that subtitles have generally been found to enhance language comprehension considerably, regardless of being interlingual or intralingual (D'YDEWALLE \& VAN DE POEL, 1999; HUANG \& ESKEY, 1999; KOOLSTRA \& BEENTJES,
1999; MARKHAM, 1999; MARKHAM \& PETER, 2003; DANAN, 2004; STEWART \& PERTUSA, 2004; TAYLOR, 2005; CAIMI, 2006; CHANG, 2006; VAN LOMMEL, LAENEN, \& D'YDEWALLE, 2006; SYDORENKO, 2010; WINKE, GASS, \& SYDORENKO, 2010; ZAREI \& RASHVAND, 2011; RAINE, 2013, to mention but a few). Another aspect that we do know is that some studies have not shown significant differences considering subtitling availability and its relationship with the specific language component being tested, such as general/listening comprehension (BIANCHI \& CIABATTONI, 2008; LATIFI, MOBALEGH, \& MOHAMMADI, 2011; SHARIF \& EBRAHIMIAN, 2013).

Comparative studies related to the effects of the use of intralingual subtitles and interlingual subtitles upon L2 learning emerged in the late 1990 's and beginning of 2000s. Until then, studies carried out to investigate the benefits and drawbacks of subtitling on language learning had typically addressed intralingual subtitles, only (captions, as to what they were often times referred). The scenario starts to change as researchers began to devote academic attention to comparative research on the effects of intralingual and interlingual subtitles related to various L2 learning domains.

In short, comparative studies that emerged from the 2000s on have presented a few grey areas. First of all, in two studies (STEWART \& PERTUSA, 2004; HAYATI \& MOHMEDI, 2011), better results were achieved with intralingual subtitles, mostly, whereas in one of the studies (MARKHAM \& PETER, 2003), better results were achieved with interlingual subtitles. Some studies presented better results with one or the other type of subtitles depending on the language component being tested or proficiency group (MARKHAM, PETER, \& MCCARTHY, 2001; BIANCHI \& CIABATTONI, 2008; LATIFI, MOBALEGH, \& MOHAMMADI, 2011; ZAREI \& RASHVAND, 2011).

When we single out studies involving university-level participants from studies involving other populations, the number adds up to a total of at least 13 pieces of research that have been published until 2016. When analyzing 
the results obtained by these studies with a focus on those that have looked at a direct comparison of intralingual subtitles and their absence, out of the six studies, the scenario we get is that four of them favor the presence of intralingual subtitles, whereas two of them found no significant differences between experimental and control groups.

When analyzing the results obtained by those studies involving universitylevel participants with a focus on those that have examined the effects of intralingual subtitles, interlingual subtitles and no subtitles comparatively, the picture we get is that out of the seven studies in this category, intralingual subtitles were found to be more effective in language development - language comprehension included - than interlingual subtitles and/or no subtitles whatsoever. A few discrepancies found in the comparative studies mostly relate to the type of test being used and the language component being tested (whether they look at more than language comprehension, for instance, and examine other macro-skills). Nevertheless, it is important to note that most studies reported in the literature involve intermediate-level participants, with varying L1 and L2 backgrounds. Hence, there is still a need for further scrutiny regarding the effects of intralingual and interlingual subtitles for language development, especially when one considers the fact that certain populations of EFL learners have been underinvestigated, Brazilian EFL learners being the case in point.

The picture becomes blurry when we factor in the simultaneous processing of audio and subtitles. Since reading subtitles has been found to be an automatic behavior on the viewers' part regardless of one's familiarity with them, knowledge of the foreign language in the soundtrack or its availability - as confirmed in studies with eye-movement recordings (D'YDEWALLE \& GIELEN, 1992; WINKE, GASS, \& SYDORENKO, 2013; KRUGER \& STEYN, 2014; MONTERO-PEREZ, PETERS, \& DESMET, 2015) - it then seems reasonable to assume that part of one's attentional resources when watching a subtitled film is allocated in reading and processing the subtitles, whereas the rest is ideally distributed between the processes of watching and attending to the story, processing the motion picture, and arguably attending to the auditory input. Hence, the ability to successfully attend to the whole set of input - the simultaneous use of spoken (audio/soundtrack) and written (interlingual and intralingual subtitles) input modes - could depend, to some degree, on the language in them, especially if that language were to be one's L1, which in turn would require less effort in terms of processing and reading efficiency.

Koskinen and colleagues (1996) posited that university-level student typically have better reading comprehension than listening comprehension skills. The authors believe that these learners may benefit most from viewing difficult target-language video material with interlingual subtitles (learners' native language). If this is true, then one may assume that the presence of interlingual subtitles could impose an extra processing burden on the viewers' part, since they would have to attend to two different languages simultaneously (foreign soundtrack and native-language subtitles), unless the L2 soundtrack were to be completely unattended at all, consciously or not. Following this rationale, one might assume that intralingual subtitles would then be less distractive for L2 learners, since they would have to attend to and process only one language in both channels (soundtrack and subtitles). This is a crucial point that still merits further investigation and does not seem to be resolved in the literature ${ }^{3}$.

\section{Method}

As stated in the introduction, this study, which is of a mixed design nature, was aimed at investigating the effects of the use of intralingual and

3 See Matielo (2016) for a study that looks at the relationship between intralingual subtitles, interlingual subtitles, and working memory capacity for some insights on this issue. 
interlingual subtitles on Brazilian EFL learners' video comprehension. In other words, this research has looked at how intralingual and interlingual subtitles affect learners' general and specific video comprehension, as measured by learners' immediate post-viewing test.

\subsection{Participants}

A total of 36 participants completed the research steps or were kept until the end of the data collection, in that 20 were female and 16 were male, all of which are Brazilian intermediate EFL learners in the 18-60 age range (mean age of 22 years old), chosen on the basis of their proficiency level, i.e., level 5 (intermediate), enrolled in the Extracurricular ${ }^{4}$ (non-credit) Language Courses at Universidade Federal de Santa Catarina (UFSC), FlorianópolisSC, Brazil. It is important to mention that studies on the effects of subtitled video materials on any language learning aspect have typically comprised intermediate learners of the language, and an assumption behind that is that these participants are usually at a threshold proficiency level that enables them to read the subtitles on screen in the L2, which may not be possible with beginning learners since subtitles are displayed on screen for 2-4 seconds only and they might have not automatized reading and processing skills yet.

Participants were randomly assigned to one of the treatment groups or the control group, namely: Intralingual Subtitles Group ( $n=12)$, Interlingual Subtitles Group ( $\mathrm{n}=12)$; and Control Group - no subtitles $(\mathrm{n}=12)$. Participants were informed about all the stages in the data collection

4 The Extracurricular (non-credit) Language Courses at UFSC are open to undergraduate and graduate students enrolled at UFSC or any other higher education institution in the area, as well as faculty members, and members of the community. Students can enroll twice a year and can take a placement test to determine their proficiency level in any of the language courses offered. In relation to English courses, language instructors consist of undergraduate and graduate students taking the Letras program, who are supervised by two coordinators. in the first meeting, when they were invited to participate in the research, signed the Consent Form (University's Ethics Committee number of approval: 36597314.9.0000.0118), and had the opportunity to clarify doubts related to the goals and the design of the study. However, participants were not told about specific details that could bias their answers during any of the stages in the data collection, though they were informed that they could ask more specific questions once the data collection was over.

Information gathered on the participants' profile through the administration of a student profile questionnaire designed specifically for the present study revealed that, by the time of data collection, most of them (75\%) had been studying English for at least three or four years, had been having contact with the English language mostly by attending EFL classes, as well as by listening to music and watching films and TV series. The questionnaire also revealed that most participants (55.6\%) had never been to an English speaking country before and most of them informed that they had been studying English because they seek professional and personal development (97.22\%).

As for their TV series viewing habits, the profile questionnaire revealed that most of them (83.36\%) reported to watch films or TV series at least twice or three times a week and, among the mostly watched TV series are Friends, Games of Thrones and How I Met Your Mother (69.25\%). The majority of all participants (86.11\%) reported watching TV series with interlingual subtitles, whereas a few of them (13.89\%) reported watching TV series with intralingual subtitles. No participant reported using dubbing or no translational aid. The participants reported that TV series are sometimes used (50\%) and frequently used (50\%) in their English classes, especially to address cultural issues, introduce the topic of a unit or develop their listening comprehension skills (75\%). 


\subsection{Materials: On the TV Series}

The participants watched a 20-minute episode of the American TV series The Big Bang Theory, which premiered in 2007. In Brazil, the series is broadcast with Portuguese subtitles on Warner Channel and is a critically acclaimed show. The sitcom depicts Leonard Hofstadter and Sheldon Cooper, two brilliant physicists who are best friends and roommates. They are also friends with their co-workers Howard Wolowitz, a mechanical engineer, and Rajesh Koothrappali, an astrophysicist. The gang spends their time working on their individual work projects, playing video games, watching sciencefiction movies, or reading comic books. As they are self-professed nerds, they have little or no luck with women. When Penny, a pretty woman and an aspiring actress that works as a waitress, moves into the apartment next to Sheldon and Leonard's, the latter has another aspiration in life, that is, to try and get Penny to be his girlfriend ${ }^{5}$.

The sitcom (situational comedy) was selected to be used in the present investigation based on a series of criteria. First of all, the series and the specific episode adopted in this research were used in Matielo, Collet, and D'Ely (2013). Additionally, they were also chosen on the basis of its genre, since a sitcom was thought to be appealing and appropriate to the target audience. From the profile questionnaire administered in the very first session in the data collection, 31 out of the 36 participants reported watching sitcoms, thus suggesting their familiarity with the genre.

The episode used in the study was "The Grasshopper Experiment", the eighth episode on the first season. In this episode, Raj's parents back in New Delhi have set him up with a childhood acquaintance of his named Lalita Gupta, who has just moved to California, hoping to get them married. Raj,

5 Information retrieved from <http://www.imdb.com/title/tt0898266>. who cannot speak to or address any woman, does not want to meet with Lalita. Meanwhile, Penny, wanting to practice her bartending skills, uses the guys as guinea pigs, which opens up a whole new world for Raj: he now realizes he can speak to Lalita (or any other woman for that matter) when under the influence of alcohol. Lalita, however, ends up having a connection on the date, but with Sheldon, instead ${ }^{6}$. The episode was chosen since it contained a complete story line and did not require students to be familiar with the series or previous episodes.

\subsection{Materials: On the Video Comprehension Test}

In order to assess participants' general comprehension of the video in terms of its content, three 'why' questions were posed and participants were instructed orally to answer them in Portuguese or in English and were assured that grammatical errors would be disregarded. Essentially, in order to successfully answer the general comprehension questions, participants were required to have some level of understanding of the story and how it unfolded throughout the episode. All of the events in the episode were highly intertwined, which meant that participants had to have some level of general comprehension as regards the connections among the goingson in the episode to be able to answer the questions. An example of such a question is: "At the end of the episode, why is Sheldon singing and playing?". Concerning the assessment of the participants' specific comprehension of the video, participants had to judge five statements about the story narrated on screen on whether they were true or false. The statements essentially provided details about the characters, their relationships, likes and dislikes, attitudes, and information about the story. An example of such statement to be judged as true or false is: "( ) Raj is used to drinking".

${ }^{6}$ Information retrieved from <http://www.imdb.com/title/tt1127389>. 


\subsection{Data Collection Procedures and Research Design}

Data collection took place during the regularly scheduled class periods in the regular classrooms with a view to minimizing disruption of the cooperating teachers' classroom schedules. In class, one of the researchers collected the data over two sessions: in the first session, the student profile questionnaire and a term of consent were administered. In the second session, prior to video watching, the participants were provided with some background information regarding the TV series, such as the plot summary and a quick introduction to the characters for story contextualization purposes using a PowerPoint ${ }^{\complement}$ presentation that took a total of 2 minutes, in Portuguese to avoid misunderstandings. Then, each group of participants were shown the video, which lasted for 20 minutes, under the different experimental conditions (intralingual subtitles, interlingual subtitles, and control group - no subtitles) in separate classrooms during their regularly scheduled classes. In this very same session, the video comprehension test was administered. The sheet of paper containing the test itself was only handed out after participants had finished watching the video to avoid influencing their responses.

The video was shown with the use of a standard DVD player with a digital image display projector and external speakers in a relatively small classroom with a large screen, with regular viewing and listening conditions. No time frame was established in any treatment conditions in order to ensure that the participants felt at ease to answer the questions. It is important to highlight that the participants were informed in advance that their participation in the research was voluntary and that their performance on the tests was unrelated to their course grades.

\subsection{Scoring of the Video Comprehension Test and Statistical Procedures}

Regarding the video comprehension test, three different raters with similar educational and professional backgrounds, chosen on the basis of relevance to this study, were invited to assist in this process, all of them experienced language teachers taking a pursuing their PhD. Raters accepted to rate tests in their entirety based on a copy of the test without the participants' identification. Raters watched the TV episode used in the present study before scoring the tests and individual conversations between the researchers and the raters about the TV series and the episode were held whenever necessary.

The raters were instructed to disregard any grammatical errors in the participants' responses. The raters were instructed to assign one point to each of the three questions in the general comprehension (why questions) of the video in case they felt that the answer provided by the participant was acceptable. In case the answer was not acceptable in the raters' perception, no points were assigned to that given question. In relation to specific comprehension of the video ( $\mathrm{T}$ or $\mathrm{F}$ questions), the same procedure was followed.

Regarding the video comprehension test - general and specific parts Shapiro-Wilk's tests $(\mathrm{p}<.05)$ and visual inspections of the histograms, $\mathrm{Q}-\mathrm{Q}$ plots, and box plots showed that the data were not approximately normally distributed, with varying skewness and kurtosis. In light of normality tests run on the data and the objective of the study, Kruskal-Wallis One-Way ANOVA tests were run to compare the performance of the two experimental and the control groups. 


\section{Results and Discussion of Findings}

This section has been divided into three subsections. Subsection 4.1 reports on the statistical tests and the results obtained for the general comprehension of the video; subsection 4.2 addresses the statistical tests and the results obtained for the specific comprehension of the video; subsection 4.3 discusses the results and highlights the main findings.

\subsection{General Comprehension: Descriptive Statistics and Results}

As regards the video comprehension test, participants were assessed in terms of their general and specific comprehension of the video. Table 1 displays the results obtained on the general comprehension part of the test, which consisted of three open-ended questions to assess participants' broader understanding of the video content and storyline.

As indicated in Table 1, participants' mean scores in the general comprehension part of the test as regards the video content were found to be different considering the two experimental conditions and the control condition. Participants in the intralingual subtitles condition $(M=2.67)$ outperformed those in the interlingual subtitles condition $(M=2.25)$, who in turn outperformed those in the control condition $(M=1.75)$. It is interesting to notice that 2 points was the minimum score obtained by the intralingual subtitles group, whereas 1 point was the minimum score obtained by the interlingual subtitles and control groups. In all groups there were participants scoring the maximum number of points in this portion of the test, though no participant scored 0 points.

The numbers provided in Table 1 signal differences in terms of the participants' ability to attend to and successfully understand the gist of the video they had watched. Furthermore, differences in the mean scores obtained by the groups were found, in spite of the fact that they are more visually salient when comparing experimental to control groups, but not the experimental groups themselves (intralingual and interlingual subtitles).

Table 1 - General comprehension results

\begin{tabular}{llcc}
\hline & Group & Statistic & Std. Error \\
\hline Intralingual & Mean & 2.67 & .142 \\
Subtitles & SD & .492 & \\
$(\mathrm{n}=12)$ & Minimum & 2 & \\
& Maximum & 3 & .637 \\
& Skewness & -.812 & 1.232 \\
& Kurtosis & -1.650 & .250 \\
Interlingual & Mean & 2.25 & \\
Subtitles & SD & .866 & \\
(n=12) & Minimum & 1 & .637 \\
& Maximum & 3 & 1.232 \\
& Skewness & -.567 & .250 \\
& Kurtosis & -1.446 & \\
Control & Mean & 1.75 & \\
$(\mathrm{n}=12)$ & SD & .866 & .637 \\
& Minimum & 1 & 1.232 \\
\hline
\end{tabular}

$\mathrm{n}=$ sample size; Std. Error=standard error; $\mathrm{SD}=$ standard deviation; Minimum number of points to be obtained in the test: 0; Maximum number of points to be obtained in the test: 3 .

Source: The authors (2017).

In order to explore possible differences in terms of the performance of the three groups on the video comprehension test (general and specific parts), Kruskal-Wallis One-Way ANOVA tests were run and the results obtained on the general comprehension part of the test indicated that the groups are statistically different from one another and that there was a significant effect of availability of subtitles on the participants' performance on the general 
comprehension of the video $(H(2)=6.806, p=.033)$. An effect $\operatorname{size}^{7}$ of $19 \%$ was found in the data, which indicates the percentage of the variability in the general comprehension scores that was accounted for by the availability of subtitles. Even though the Kruskal-Wallis One-Way ANOVA test does inform that the three groups are statistically different, it does not inform where the difference is. Further separate Kruskal-Wallis One-Way ANOVA tests ${ }^{8}$ were therefore run as post-hoc tests between two groups at a time. This allows to spot where the statistically significant differences among them lie.

The differences found between the experimental groups - intralingual and interlingual subtitles - are not statistically significant $(\mathrm{H}(2)=1.293$, $\mathrm{p}>.05$ ), though the former obtained higher mean scores than the latter. Similarly, the differences found between the interlingual subtitles group and the control group are not statistically significant either $(H(2)=1.917, p>.05)$. However, when observing the results of the statistical test run between the intralingual subtitles and the control groups, it is possible to state that this is where the statistically significant difference is $(\mathrm{H}(2)=6.799, \mathrm{p}=.009)$. Thus, the Kruskal-Wallis One-Way ANOVA test confirms that these are the two groups that are statistically different - intralingual subtitles and control groups - and reveals that the availability of intralingual subtitles impacted positively on the participants' level of general comprehension of the video as compared to the control group.

\subsection{Specific Comprehension: Descriptive Statistics and Results}

Participants were also assessed on their specific comprehension level of the video in terms of their ability to attend to and understand specific

\footnotetext{
In this study, an effect size was calculated by taking the chi-square value divided by $\mathrm{n}-1$.

8 The same results can be obtained by running Mann-Whitney U Tests, given that the data are not approximately normally distributed. The researchers ran further separate Kruskal-Wallis One-Way ANOVA tests for the sake of convenience.
}

details about the video content and the storyline. This portion of the video comprehension test contained five statements of a true or false nature, as explained in the Method. Participants' performance on the specific comprehension test is displayed in Table 2:

Table 2 - Specific comprehension results

\begin{tabular}{llcc}
\hline & Group & Statistic & Std. Error \\
Intralingual & Mean & 4.67 & .188 \\
$\begin{array}{l}\text { Subtitles } \\
(\mathrm{n}=12)\end{array}$ & SD & .651 & \\
& Minimum & 3 & \\
& Maximum & 5 & .637 \\
& Skewness & -1.930 & 1.232 \\
& Kurtosis & 3.165 & .256 \\
Interlingual & Mean & 4.33 & \\
Subtitles & $\mathrm{n}=12)$ & .888 & \\
& SD & 3 & .637 \\
& Minimum & 5 & 1.232 \\
& Maximum & -.797 & .241 \\
Control & Skewness & -1.269 & \\
$(\mathrm{n}=12)$ & Kurtosis & 3.83 & \\
& Mean & .835 & .637 \\
& SD & 3 & 1.232 \\
\hline
\end{tabular}

$\mathrm{n}=$ sample size; Std. Error=standard error; $\mathrm{SD}=$ standard deviation; Minimum number of points to be obtained in the test: 0; Maximum number of points to be obtained in the test: 5 . Source: The authors (2017).

As shown in Table 2, participants' mean scores on the specific comprehension part of the test about the video are dissimilar considering the two experimental conditions and the control condition of the experiment. Participants in the intralingual subtitles condition $(M=4.67)$ 
outperformed those in the interlingual subtitles condition $(M=4.33)$, who in turn outperformed those in the control condition $(M=3.83)$. In all three groups, 3 and 5 were the minimum and maximum scores obtained on the test, respectively.

Now, because there is observable variance concerning the performance of the three groups as regards the specific comprehension on the video comprehension test, a Kruskal-Wallis One-Way ANOVA test with the three groups together was performed. The results from the Kruskal-Wallis OneWay ANOVA test run on the specific comprehension part of the test indicated that the three groups are statistically different and the test revealed that there was a significant effect of availability of subtitles on the participants' performance on the specific comprehension of the video $(\mathrm{H}(2)=6.113$, $\mathrm{p}=.047)$. An effect size of $19 \%$ was also found in the data, which indicates the percentage of the variability in the specific comprehension scores that was accounted for by the availability of subtitles, as it did on the general comprehension portion of the test.

Further separate Kruskal-Wallis One-Way ANOVA tests were then run between two groups at a time to precisely determine which groups are statistically different from one another. Taken together, the results obtained with the three separate Kruskal-Wallis One-Way ANOVA tests on the specific comprehension part of the test allowed to determine where the statistically significant differences among the groups are. The differences found between the experimental groups - intralingual and interlingual subtitles - are not statistically significant $(\mathrm{H}(2)=.939, \mathrm{p}>.05)$, though the former obtained higher mean scores than the latter. Likewise, the differences found between the interlingual subtitles group and the control group are not statistically significant either $(\mathrm{H}(2)=2.012, \mathrm{p}>.05)$. However, when observing the results of the statistical test between the intralingual subtitles and the control groups, statistically significant differences between these two groups were found $(H(2)=5.998, p=.014)$. Hence, the presence of intralingual subtitles positively affected the intralingual subtitles group's level of specific comprehension of the video in comparison to the control group.

\subsection{Intralingual Subtitles, Interlingual Subtitles, and Video Comprehension: Discussion of the Main Findings}

The effects of subtitling on L2 comprehension has been, to some degree, perhaps one of the most well documented aspects in the literature, especially when it comes to European and other multilingual populations. As Vanderplank (2015) rightly put, the picture that has been built up with the literature is very informative in that the last thirty years of research into intralingual subtitles have confirmed repeatedly positive effects on (L2) language learning. Nonetheless, issues related to the contrastive nature of intralingual subtitles and interlingual subtitles, as well as long-term language development have still yet to be fully investigated.

In the present study, the results obtained with the general and specific video comprehension parts of the test revealed that the availability of intralingual subtitles was more beneficial than the availability of interlingual subtitles or no subtitles whatsoever, though interlingual subtitles were found to aid comprehension just like intralingual subtitles were, from a statistical point of view. While the latter led participants to a significantly higher level of general and specific comprehension of the video material (content) and storyline, interlingual subtitles and control conditions were not statistically different from each other. This result is tune with early single modalities studies (intralingual subtitles vs. soundtrack, only), such as those by Garza (1991) and Huang and Eskey (1999), who found that participants' content comprehension was larger when intralingual subtitles were available in comparison to listening to the soundtrack without any textual aid. 
The results obtained on the general and specific portions of the video comprehension test are also fairly aligned with some of those comparative (intralingual vs. interlingual subtitles) studies reported in the literature, such as Stewart and Pertusa (2004) and Hayati and Mohmedi (2011). These two pieces of research found that better performance was obtained when intralingual subtitles were available to the informants, rather than interlingual subtitles or soundtrack only. This pattern was observed in the results obtained in the present research. However, the results obtained here are not aligned with those reported in Markham, Peter, and McCarthy (2001), Markham and Peter (2003), and Latifi, Mobalegh, and Mohammadi (2011). In those studies, participants' level of video comprehension was higher when interlingual subtitles were available, rather than intralingual subtitles.

The debate around the empirical research on the use of intralingual subtitles versus interlingual subtitles to foster video comprehension is far from black and white, and its grey areas are filled with sensitive issues that have not been fully investigated yet. As previously mentioned, for instance, Koskinen and colleagues (1996) posited that university-level students generally have better reading comprehension than listening comprehension skills and thus would benefit most if target-material was presented in the subtitles, that is, in this case, in the form of intralingual subtitles. If true, participants' frequent reliance on reading would partially explain the results found in the present investigation. It would also confirm that the participants in the interlingual subtitles and control groups did not have the same opportunity to read the target-material in the L2, even though a translation was made available in the case of interlingual subtitles and the L2 was provided in the soundtrack.

Another sensitive issue that arises in the intralingual subtitles versus interlingual subtitles equation that could, in part, explain the results obtained here and elsewhere (STEWART \& PERTUSA, 2004) concerns the informants' attitudes towards subtitling. Not very often do researchers survey participants on how they feel about using intralingual and interlingual subtitles with a view to improving their understanding of the film content. In their study, Stewart and Pertusa comment that the surveys with their learners revealed that $65 \%$ of them prefer intralingual subtitles over interlingual ones, even if they had not been frequently watching videos with intralingual subtitles.

This particular piece of information speaks to the learners' beliefs and attitudes towards subtitling, which can have a direct impact upon their L2 development. In the present research, data gathered with the student profile questionnaire was very relevant because it outlines an interesting viewing profile. In relation to the participants in the intralingual subtitles group, $75 \%$ of them reported watching videos with Portuguese subtitles more often (twice or three times a week), whereas this number in the interlingual subtitles group amounted to around $92 \%$ and to $67 \%$ in the control group.

Although these numbers differ, they might not be enough to explain the results obtained on the general and specific parts of the video comprehension test, though they may trigger some valid insights. They may, for one, contribute to the speculation that these participants are likely to prioritize one input modality. Participants received information from two or even three competing channels or sources of input, involving two different languages. On the one hand, the audio/soundtrack in English, with challenging material to which they should attend, process, and understand; on the other hand, English or Portuguese subtitles, whose reading is also a highly cognitive demanding task, given the short period of time that subtitles last on screen (from 2-4 seconds at the most). Moreover, one cannot forget about the visual channel that certainly is attention drawing and does require some processing, after all, it is unlikely that one watches a subtitled film and processes audio and text only. 
On this very issue - the processing of images in a subtitled film - the few existing eye-tracking methodology-based studies on subtitling and L2 development so far have substantially enlarged our body of knowledge of what learners do when engaged in subtitled video watching tasks. Sydorenko (2010) reported that her beginning participants found images to be more useful than intralingual subtitles; Bisson et al (2014) found that participants tended to read the subtitles irrespective of the language in them (native or foreign) and also tended to spend more fixation time on the subtitles area when they were in a foreign language and then moved on to the images on screen.

In the present research, the fact that participants in the intralingual subtitles group outperformed those in the interlingual subtitles and control groups suggests that receiving the same input from two different competing channels (audio and subtitles), but on the same language (English) proved to be more slightly effective for content comprehension. Furthermore, it is worthwhile pointing out that the general and specific comprehension questions administered immediately after viewing were in English, which may have also facilitated or even boosted those participants' level of comprehension in the intralingual subtitles condition. As for those in the control condition, evidence from the results suggests that the video itself may have been challenging and some of its parts may have not even been processed.

Bianchi and Ciabattoni (2008) go as far as arguing that "subtitling is processed automatically and content comprehension can logically be facilitated by text in the mother tongue" (p. 78), which certainly does not seem to be the case here. In their experiment, intermediate-level learners performed better on comprehension tests using intralingual subtitles of one video (Frantasia) and the same participants performed better on comprehension tests using interlingual subtitles of another video (Harry Potter), as compared to the control group (soundtrack only).
Drawing on these results and the ones obtained in the present research, we posit that the participants in the interlingual subtitles group may have tried to process both input modalities - audio and subtitles - and were then faced with a cognitive challenge, thus compelling them to attend to and process both sources of information containing two different languages while simultaneously paying attention to the video (images). Conversely, participants in the control group may have been overwhelmed as regards the fact that no textual aid was provided that they might have relied more on the video per se when realizing that the input provided in the audio could be difficult to attend to and process. It is important to highlight that most participants in the control group were used to watching subtitled videos with interlingual subtitles, as reported in their retrospective questionnaires.

This represents another sensitive issue in dealing with the use of subtitled video materials. The presence of one auditory channel and two visual channels - one being verbal and another being non-verbal - constructs a scenario in which the learner may and sometimes must choose one of the visual channels to prioritize for processing efficiency reasons, especially if that learner has not yet mastered the video's target-language. Noticeably, the choice of which source of input to focus on is probably linked to a myriad of variables, learning styles possibly being one of them. Auditory-oriented types of learners may perhaps cater for the auditory channel more than the subtitles, whereas visually-oriented types of learners may consciously or even unconsciously decide to focus more on the subtitles and the video instead.

Perego and colleagues (2010) hypothesized that when attention is more focused on the subtitles per se, image processing would be less effective and that the opposite would be true as well. Their rationale was generally consistent with attentional theories that postulate early selection of information channels. The results in their experiment demonstrated that, 
in general, participants presented a pattern of attentional allocation, in that they willingly decided to pay more attention to the written input, rather than the visual one.

Another interesting finding is provided by Taylor (2005), who surveyed 35 learners (17 beginners and 18 intermediate Spanish learners) on their perceptions of subtitles (intralingual ones being the case in point). In the survey, $35 \%$ of the beginners stated that subtitles are distracting and confusing. The same learners also reported that they find it extremely difficult to use the three channels simultaneously. However, it is quite interesting to notice that only $11 \%$ of the intermediate learners reported similar difficulties. Another very relevant finding is that more intermediate than beginning learners of Spanish in that survey admitted that they were able to use all three channels with a view to facilitating their comprehension of the video material.

In light of Taylor's survey results combined with the present study's results, it might be that as learners progress in terms of their $\mathrm{L} 2$ development, and therefore develop sharper listening comprehension skills, their need to rely on subtitles can be expected to decrease. Consequently, it is also expected that learners will not need to depend on subtitles to understand the video content as much. This has been regarded in the literature as "subtitles as a crutch" (WINKE, GASS \& SYDORENKO, 2010, p. 65), in that subtitles would facilitate or even enhance comprehension when the input provided is not very accessible or cannot be entirely attended to and processed through the auditory channel alone. With time, as one becomes more proficient in their L2 listening skills - and even more confident - their dependence on subtitles is likely to become more peripheral.

Taylor's survey also revealed that some participants ( 9 out of the 35 participants, 4 being beginners and 5 being intermediate-level) did mention that they completely ignored the soundtrack and focused on the subtitles alone. The implications behind such a statement are far reaching, but we must be weary given that the population in that study comprised both beginners and intermediate-level learners and what participants reported having done may not actually correspond to what they actually did on the tests.

Going back to the results on the general and specific portions of the video comprehension test, the statistical tests and analyses performed revealed that the intralingual and interlingual subtitles groups were not statistically different from one another, even though the former outperformed the latter as regards both general and specific comprehension of the video material. It might have been the case that both groups obtained high scores on the test by relying on their preferred source of input, regardless of the language in it. For comprehension purposes, such a strategy would have sufficed for either intralingual or interlingual subtitles group, but not for the control group. It is, to some degree, safe to assume that participants in the experimental groups might have possibly relied on the reading of subtitles mostly in order to get the necessary information to make sense of what was being narrated on screen. The lower mean scores obtained by the control group would confirm this assumption because they could only have relied on their listening skills of a verbal source of input (soundtrack) of a challenging video and the images per se since no subtitles were made available in that condition.

One more aspect that deserves mentioning relates to the language used in the responses to the questions on the general portion of the video comprehension test. As previously described in the Method, participants were told that they could answer the questions in either English or Portuguese and their responses were not scrutinized by the raters. Instead, the raters were instructed to judge them as being appropriate or not as far as they could indicate comprehension. Surprisingly, more participants in the intralingual subtitles $(75 \%)$ and control $(\approx 84 \%)$ groups answered the 
questions in English, whilst fewer participants $(\approx 34 \%)$ in the interlingual subtitles group used English to respond to the questions. These numbers may also be indicative of the channel to which participants may have attended more often.

\section{Concluding remarks}

This study set out to investigate the effects of intralingual and interlingual subtitles on Brazilian EFL learners' general and specific video comprehension. In short, the results of the statistical tests and the analyses performed indicate that there were more beneficial effects on general and specific video comprehension when using intralingual subtitles over interlingual subtitles or control conditions. Nonetheless, participants' performance in the experimental conditions - intralingual subtitles and interlingual subtitles - on both general and specific portions of the video comprehension test were not statistically different from one another. Yet, participants in the intralingual subtitles condition did outperform those in the control group and the differences between these two groups were found to be statistically significant.

Unfortunately, the researchers did not include a specific question to gather more data that could further enlighten the issue of whether participants attempted to process all channels altogether. Nonetheless, in informal conversation held with them, participants informed that they usually find it very difficult to sustain attention to auditory and visual channels simultaneously. Interestingly, a few of them also mentioned that the more they get used to a certain TV series, by watching several episodes over the week, the less they tend to rely on the subtitles, be they intralingual or interlingual ones, because they mentioned that with time, they get acquainted with characters' accent and the jargons used in the series.
Even though it is not possible to quantify or systematize this response given by the informants because they are solely based on the researchers' recollections, they provide some basis for the speculation that the type of video content, its genre or video familiarity may have also played a role in determining learners' video comprehension of subtitled material. In fact, the relationship between content familiarity and subtitling has been a variable that has merited previous research attention in the niche. Markham, Peter, and McCarthy's (2001) revealed that participants' level of recall of the video content was much lower when no subtitles were available than when they were for non-familiar material, that is, for video materials with which participants were not so familiar in terms of content/genre. Also, Winke, Gass, and Sydorenko's (2013) eye-tracking study demonstrated that video content familiarity correlated with the type of L2 being learned, which, in that case, was Chinese, a language that required more processing of subtitles with a video that was deemed more difficult for the kind of topic it portrayed, being unfamiliar to the participants.

A final aspect that needs to be considered is the lack of proper test announcement prior to video watching in the study. Test announcement has indeed been found to correlate with participants' better performance on tests. Winke, Gass, and Sydorenko (2013) found that their participants in the test announcement condition using full captioning or keyword captioning performed better than participants who did not receive a test announcement before watching the video in those conditions. The authors posit that test announcement possibly prompted them to reanalyze the content of the subtitles more closely, thus spending additional time on the subtitles area to process it more effortfully and therefore gather more information to understand the narration.

In this study, since no test announcement was included, participants were not watching the video with a pre-established goal in mind, which makes 
it somewhat difficult to infer with which mindset participants watched it. This means that they did not know whether they were supposed to focus attention on any specific piece of information from the video, nor did they know the nature of the upcoming tests that they would perform.

A closer look at the specific comprehension test design may raise a question as to the possibility of guessing on the participants' part, given that it was of a True or False format. However, when comparing the participants' performance across the three groups on the two parts of the test - general and specific comprehension parts - there is evidence in the scores that suggests a trend. Such a trend consists of better performance by the intralingual subtitles group on both parts of the test in comparison to the interlingual subtitles group and then the control group. The results have thus led the researchers to rule out guessing as a determining variable upon the scores obtained.

The results hereby obtained reinforce the pedagogical potentials and limitations that such translational aids may pose to L2 practitioners. To begin with, given the expanding use of subtitled audiovisual materials in and outside L2 classrooms and the technological advances we are currently witnessing, we find it crucial for L2 practitioners to help learners develop strategies to benefit from subtitled video materials. This means that L2 instructors should consider helping learners to cope with possible cognitive (over)load that these materials may present, especially when any textual aid (subtitles) is used. Directing learners' attention to specific features of the video material presented may be a good start to achieve that.

Additionally, a very sensitive issue that has almost been neglected in the literature regards the notion that subtitles are in fact being used as crutches. The goal behind the use of subtitled video materials is to ensure that learners who have not yet mastered a certain L2 may still benefit from that material in terms of its comprehension. However, there might come a time when subtitles may have to be abandoned. Very little is discussed in the literature in terms of whether the constant use of subtitled video materials effectively contribute to one's listening comprehension skills development or whether they cause some kind of 'dependence'.

To conclude, we hope that this paper has been able to address relevant questions regarding the effects of intralingual and interlingual subtitles upon L2 video comprehension. We also hope that the theoretical discussions presented in light of the results obtained may contribute to establishing a fruitful dialogue amongst the many fascinating areas and research niches within the disciplinary field of SLA. Finally, and perhaps most importantly, we also hope that these results may positively influence upcoming research and help L2 practitioners reflect and make knowledgeable choices as regards their L2 instruction using subtitled video materials.

This study was sponsored by the Conselho Nacional de Desenvolvimento Científico e Tecnológico (CNPq) - Brazil.

\section{References}

ANDERSON, Daniel; Collins, Patricia. The impact on children's education: Television's influence on cognitive development. Washington, DC: U.S. Department of Education, Office of Educational Research and Improvement, 1988.

ATKINSON, David. The mother tongue in the classroom: a neglected resource? English Language Teaching Journal, v. 41, n. 4, p. 241-247, 1987.

AUERBACH, Elsa R. Reexamining English only in the ESL classroom. TESOL Quarterly, v. 27, n. 1, p. 9-32, 1993.

BIANCHI, Francesca; CIABATTONI, Tiziana. Captions and subtitles in EFL learning an investigative study in a comprehensive computer environment. Disponível em: <http:// www.openstarts.units.it/dspace/bitstream/10077/2848/1/bianchi_ciabattoni.pdf $>$. Acesso em: 20 jan. 2017. 
BIRD, Stephen; WILLIAMS, John. The effect of bimodal input on implicit and explicit memory: an investigation into the benefits of within-language subtitling. Applied Psycholinguistics, v. 23, n. 4, p. 509-533, 2002.

CAIMI, Annamaria. Audiovisual Translation and Language Learning. The Promotion of Intralingual Subtitles. Journal of Specialised Translation, v. 6, p. 85-98, 2006.

CHANG, Suhsun. The Interaction Between Schemata and Subtitles. Journal of National Taipei University of Technology, v. 39, n. 1, p. 209-227, 2006.

CHEN, Mei-Ling. Effects of the Order of Reading Text or Viewing a Film and L1/L2 Captions on Reading Comprehension. Perceptual \& Motor Skills, v. 115, n. 1, p. 18-26, 2012.

DANAN, Marine. Captioning and subtitling: Undervalued language learning strategies. Meta, v. 49, n. 1, p. 67-77, 2004

D’YDEWALLE, Géry; GIELEN, Ingrid. Attention allocation with overlapping sound, image, and text. In RAYNER, Keith. (Ed.). Eye movements and visual cognition: Scene perception and reading. New York: Springer-Verlag, 1992. p. 415-427.

D’YDEWALLE, Géry; VAN DE POEL, Marijke. Incidental foreign-language acquisition by children watching subtitled television programs. Journal of Psycholinguistic Research, v. 28, p. 227-244, 1999 .

ELLIS, Rod. The study of second language acquisition. 2. ed. Oxford: Oxford University Press, 2008.

GARZA, Thomas J. Evaluating the use of captioned video materials in advanced foreign language learning. Foreign Language Annals, v. 24, n. 3, p. 239-258, 1991.

HAYATI, Abdolmajid; MOHMEDI, Firooz. The effect of films with and without subtitles on listening comprehension of ESL learners. British Journal of Educational Technology, v. 42, n. 1, p. 181-192, 2011.

HUANG, Hsin-Chuan; ESKEY, David E. The effects of closed-captioned television on the listening comprehension of intermediate English as a second language (ESL) students. Journal of Educational Technology Systems, v. 28, p. 75-96, 1999.

KOOSLTRA, Cees M.; BEENTJES, Jonannes W. J. Children vocabulary acquisition in a foreign language through watching subtitled television programs at home. ETR\&D, v. 47, n. 1, p. 51-60, 1999.

KOSKINEN, Patricia S.; KNABLE, James E.; MARKHAM, Paul L.; JENSEMA, Carl J.; KANE, Kathryn W. Captioned Television and the Vocabulary Acquisition of Adult Second Language Correctional Facility Residents. Journal of Educational Technology Systems, v. 24, n. 4, p. 359-373, 1996.
KRASHEN, Stephen. Principles and Practice in Second Language Acquisition. Pergamon Press, $1982 / 2009$

KRUGER, Jan-Louis; STEYN, Faans. Subtitles and Eye Tracking: Reading and Performance. Reading Research Quarterly, v. 49, n. 1, p. 105-120, 2014.

LATIFI, Mehdi; MOBALEGH, Ali; MOHAMMADI, Elham. Movie Subtitles and the Improvement of Listening Comprehension Ability. Does it help? Journal of Language Teaching and Learning, v. 1, n. 2, p. 18-29, 2011.

MARKHAM, Paul L. Captioned videotapes and second-language listening word recognition. Foreign Language Annals, v. 32, n. 3, p. 321-328, 1999.

MARKHAM, Paul L.; PETER, Lizette. The influence of English language and Spanish language captions on foreign language listening/reading comprehension. Journal of Educational Technology Systems, v. 31, n. 3, p. 331-341, 2003.

MARKHAM, Paul L.; PETER, Lizette; MCCARTHY, Teresa. The effects of native language vs. target language captions on foreign language students' DVD video comprehension. Foreign Language Annals, v. 34, n. 5, p. 439-445, 2001.

MATIELO, Rafael. Intralingual Subtitles, Interlingual Subtitles, and L2 Vocabulary Learning. An Exploratory Study with Brazilian EFL Students. 2016. 272 fl. Tese (Doutorado em Letras Inglês) -- Universidade Federal de Santa Catarina, Florianópolis, 2016.

MATIELO, Rafael; COLLET, Thaís; D’ELY, Raquel C. S. F. The effects of interlingual and intralingual subtitles on vocabulary learning by Brazilian EFL learners. An exploratory study. Revista Intercâmbio, v. 27, p. 83-99, 2013.

MONTERO-PEREZ, Maribel; PETERS, Elke; DESMET, Piet. Enhancing Vocabulary Learning through Captioned Video. An Eye-Tracking Study. Modern Language Journal, v. 99, n. 2 p. 308-328, 2015

NEUMAN, Susan B. The impact of different media on children's story comprehension. Reading Research and Instruction, v. 28, p. 38-47, 1989

NEUMAN, Susan B.; KOSKINEN, Patricia. Captioned television as comprehensible input: Effects of incidental word learning from context for language minority students. Reading Research Quarterly, v. 27, p. 94-106, 1992.

PEREGO, Elisa; DEL MISSIER, Fabio; PORTA, Marco; MOSCONI, Mauro. The Cognitive Effectivesness of Subtitle Processing. Media Psychology, v. 13, p. 243-272, 2010.

PETERS, Elke; HEYNEN, Eva; PUIMÈGE, Eva. Learning vocabulary through audiovisual input. The differential effect of L1 subtitles and captions. System, v. 63, p. 134-148, 2016. 
PRICE, Karen. Closed-Captioned TV. An Untapped Resource. MATSOL Newsletter, v. 12, n. 2, p. 1-8, 1983

RAINE, Paul. Incidental Increase in Depth of Vocabulary Knowledge Through the Viewing of Subtitled, Authentic Videos. In: SONDA, Nozomu; KRAUSE, Aleda (Ed.). Making a Difference. Tokyo: JALT, 2013. p. 492-505.

ROMANELLI, Sergio. O uso da tradução no ensino-aprendizagem das línguas estrangeiras. Revista Horizontes de Linguística Aplicada, v. 8, n. 2, p. 200-219, 2009.

SAEEDI, Zari; BIRI, Aso. The Application of Technology in Teaching Grammar to EFL Learners. The Role of Animated Sitcoms. Teaching English with Technology, v. 16, n. 2, p.18-39, 2016.

SHARIF, Masoud R.; EBRAHIMIAN, Maryam. A Comparative Study of 'Subtitled' vs. 'Auditory' Documentaries Comprehension among Persian Speakers of English. International Journal of Applied Linguistics \& English Literature, v. 2, n. 2, p. 185-192, 2013.

STEWART, Melissa A.; PERTUSA, Immaculada. Gains to language learners from viewing target language closed-captioned films. Foreign Language Annals, v. 37, n. 3, p. 438-447, 2004.

SU, Shu-Chin; LIANG, Eleen. Using Subtitled Animated Cartoons and Textbook-based CDs to Test Elementary Students' English Listening and Reading Comprehension in a Cram School. International Journal of Applied Linguistics \& English Literature, v. 4, n. 1, p. 106-114, 2015.

SYDORENKO, Tetyana. Modality of Input and Vocabulary Acquisition. Language Learning \& Technology, v. 14, n. 2, p. 50-73, 2010.

TAYLOR, Gregory. Perceived processing strategies of students watching captioned video. Foreign Language Annals, v. 38, n. 3, p. 422-427, 2005

VAN LOMMEL, Sven; LAENEN, Annouschka; D’YDEWALLE, Géry. Foreign grammar acquisition while watching subtitled television programs. British Journal of Educational Psychology, v. 76, p. 243-258, 2006.

VANDERPLANK, Robert Captioned Media in Foreign Language Learning and Teaching. Subtitles for the Deaf and Hard-of-Hearing as Tools for Language Learning. London: Palgrave Macmillan, 2015.

WANG, Yu-Chia. Learning L2 Vocabulary with American TV Drama. From the Learner's Perspective. English Language Teaching, v. 5, n. 8, p. 217-225, 2012.
WINKE, Paula; GASS, Susan; SYDORENKO, Tetyana. The effects of captioning videos used for foreign language listening activities. Language Learning and Technology, v. 14, n. 1 , p. 65-86, 2010.

WINKE, Paula; GASS, Susan; SYDORENKO, Tetyana. Factors Influencing the Use of Captions by Foreign Language Learners. An Eye-Tracking Study. Modern Language Journal, v. 97, n. 1, p. 254-275, 2013.

ZAREI, Abbas Ali; RASHVAND, Zohreh. The Effect of Interlingual and Intralingual, Verbatim and Nonverbatim Subtitles on L2 Vocabulary Comprehension and Production. Journal of Language Teaching and Research, v. 2, n. 3, p. 618-625, 2011.

Recebido em 20/01/2017 Aceito em 15/07/2017 